\begin{tabular}{lr}
\hline Jurnal Abdimas llmiah & JURNAL ABDIMAS ILMIAH CITRA BAKTI \\
Citra Bakti & Volume 2, Nomor 1, April 2021 \\
(JAICB) & ISSN 2721-9178 \\
\hline
\end{tabular}

\title{
IMPLEMENTASI PERUBAHAN PERILAKU DI KOTA DENPASAR
}

\author{
Ni Luh Putu Devhy 1), Ika Setya Purwanti'2), dan Diah Prihatiningsih ${ }^{3)}$ \\ ${ }^{1,2)}$ Rekam Medis dan informasi Kesehatan STIKES Wira Medika Bali, ${ }^{3}$ TLM STIKES Wira \\ Medika Bali \\ ${ }^{1)}$ deevhy@gmail.com, ${ }^{2)}$ dhaviata@gmail.com, 3 diahciprik@gmail.com
}

\begin{tabular}{|c|c|}
\hline Histori artikel & Abstrak \\
\hline $\begin{array}{l}\text { Received: } \\
\text { 17 Januari } 2021 \\
\\
\text { Accepted: } \\
\text { 08 April } 2021 \\
\\
\text { Published: } \\
\text { 19 April } 2021\end{array}$ & $\begin{array}{l}\text { Dunia saat ini tengah menghadapi pandemi COVID-19 yang sudah } \\
\text { berlangsung sejak } 1 \text { tahun terakhir, Indonesia pun tidak luput dari } \\
\text { pandemi COVID-19. Di Masa pandemi ini sangat penting } \\
\text { memberikan edukasi untuk menerapkan hidup sehat yaitu dengan } \\
\text { cara menggunakan masker, mencuci tangan dan menjaga jarak } \\
\text { (3M), sebagai upaya pemutusan rantai penularan Corona virus } \\
\text { khususnya di Kota Denpasar. Pengabdian kepada Masyarakat ini } \\
\text { dilakukan pada bulan November sampai dengan bulan Desember } \\
2020 \text { yang bertujuan untuk memberikan edukasi pentingnya } \\
\text { penerapan } 3 \mathrm{M} \text { dalam kehidupan sehari-hari. Pengabdian kepada } \\
\text { masyarakat (PKM) dilakukan di wilayah kota Denpasar, dengan } \\
\text { mengedukasi sebanyak } 3.450 \text { orang dengan cara menanti } \\
\text { penggunjung yang ada yang ada di } 4 \text { rumah makan. Metode } \\
\text { pengabdian kepada Masyarakat ini yaitu dengan melakukan edukasi } \\
\text { kepada pelanggan yang datang seperti meningatkan pelanggan } \\
\text { untuk mencuci tangan sebelum masuk ke restauran, memakai } \\
\text { masker dan menjaga jarak. Hasil yang kami dapatkan adalah } \\
\text { antusisme masyarakat pada saat diberikan edukasi untuk } \\
\text { penerapan 3M hal ini dapat dilihat dari masyarakat (pengunjung) } \\
\text { yang mau menerapkan } 3 \mathrm{M} \text { pada saat akan masuk ke dalam rumah } \\
\text { makan }\end{array}$ \\
\hline
\end{tabular}

Kata-kata Kunci: pandemic COVID-19, pengabdian kepada masyarakat, implementasi perubahan perilaku 
Abstract. The world is currently facing the COVID-19 pandemic that has been going on for the last 1 year, Indonesia has not escaped the COVID-19 pandemic. In this pandemic period is very important to provide education to apply $3 \mathrm{M}$, clean living as an effort to break the chain of transmission of Corona virus, especially in the city of Denpasar. This community service was carried out from November to December 2020 which aims to educate the importance of the application of $3 \mathrm{M}$ in daily life. This method of community service is by educating the community and providing counseling on $3 \mathrm{M}$. The result that we get is the antusism of the community when given education for the application of $3 \mathrm{M}$ can be seen from the community who want to apply $3 \mathrm{M}$ in their daily activities.

Keywords: COVID-19, community service, education

\section{PENDAHULUAN}

Indonesia merupakan salah satu negara yang tengah menghadapi pandemi COVID19. COVID-19 merupakan penyakit yang dapat menular dari manusia ke manusia melalui percikan air liur yg disebabkan dari batuk/bersin (droplet) yang pertama kali ditemukan di kota Wuhan china tepatnya di ibukota Provinsi Hubei China pada bulan Desember 2019 dan semenjak itu menyebar secara global (World Health Organization, 2020).

Di Indonesia penyakit COVID-19 sampai 19 Mei 2020 yang terkonfirmasi coronavirus dilaporkan sebanyak 17,644 kasus dari 34 Provinsi yaitu: Bali, Banten, DIY, DKI Jakarta, Jambi, Jawa Barat, Jawa Tengah, Jawa Timur, Kalimantan Barat, Kalimantan Timur, Kalimantan Tengah, Kalimantan Selatan, Kep. Riau, Nusa Tenggara Barat, Sumatera Selatan, Sumatera Utara, Sulawesi Utara, Sulawesi Tenggara, Sulawesi Selatan, Lampung, Riau, Maluku Utara, Maluku, Aceh, Gorontalo, Kepulauan Bangka Belitung dan Papua (Satuan Tugas Penanganan COVID-19, 2020). Beberapa Povinsi di Indonesia yang termasuk wilayah dengan transmisi lokal adalah DKI Jakarta, Banten (Kab. Tangerang, Kota Tangerang), Jawa Barat (Kota Bandung, Kab. Bekasi, Kota Bekasi, Kota Depok, Kab. Bogor, Kab. Bogor, Kab. Karawang), Jawa Timur (kab. Malang, Kab. Magetan dan Kota Surabaya) dan Jawa Tengah (Kota Surakarta) (Kementerian Kesehatan Republik Indonesia, 2020).

Kota Denpasar merupakan salah satu kota yang ada di Bali. Denpasar dibagi menjadi 4 bagian yaitu Denpasar Selatan, Denpasar utara, Denpasar Timur dan Denpasar Selatan. Kota Denpasar secara keseluruhan memiliki 962.900 jiwa (BadanPusat Statistik, n.d.). Pada bulan September 2020 di Bali khususnya kota Denpasar mengalami peningkatan kasus yang signifikan yaitu didapatkan sebanyak 7.996 kasus (Pemerintah Daerah, 2020). $\mathrm{Hal}$ ini menyebabkan pemerintah mengambil keputusan untuk memberlakukan pembatasan sosial berskala besar (PSBB) dalam rangka percepatan penanganan coronavirus diseases (COVID-19), kemudian upaya pemerintah dalam pemutusan rantai penyebaran COVID-19 dengan mengeluarkan peraturan yang mengharuskan kepada seluruh masyarakat untuk menggunakan masker pada saat keluar rumah atau berada ditempat umum baik dalam keadaan sakit maupun sehat (P.P Nomor 21 Tentang Pembatasan berskala Besar Dalam Rangka Percepatan Penanganan Corona Virus Disease 2019 (Covid-19), 2020).

Berdasarkan pemaparan diatas kami dosen dari STIKes Wira Medika mengadakan pengabdian kepada masyarakat $(\mathrm{PkM})$ yang bertujuan untuk mengedukasi masyarakat 
khususnya Kota Denpasar untuk menerapkan 3M yaitu menggunakan masker, menjaga jarak, dan mencuci tangan.

\section{METODE PELAKSANAAN}

Pengabdian Kepada Masyarakat kami lakukan di Kota Denpasar pada bulan November sampai dengan bulan Desember 2020. Khalayak sasaran dalam kegiatan ini adalah masyarakat umum di Kota Denpasar. Jumlah masyarakat yang kami edukasi sebanyak 3.450 orang dengan cara menanti penggunjung yang ada di Mie Kober sebanyak 30 orang perhari, kemudian di Mie Gacoan sebanyak 30 orang perhari, kopi sehati sebanyak 25 orang perhari, dan di Indomaret 30 orang perhari. Edukasi selama 3-6 jam perhari. Guna mencapai tujuan dalam PkM ini kami menggunakan metode:

a) Mengedukasi masyarakat untuk melaksanakan $3 \mathrm{M}$.

b) Pembagian masker dan hand sanitaiser. PkM ini tidak dilakukan evaluasi karena keterbatasan biaya, kemudian dikarenakan kami melakukan PkM di tempat makan sehingga tidak memungkinkan untuk meminta pengunjung untuk menjawab pertanyaan dari kami.

Kegiatan edukasi ini melibatkan masyarakat dan pihak terkait, sehingga tim melakukan edukasi tetap menerapkan protokol kesehatan (PROKES) seperti menggunakan masker, menjaga jarak.

\section{HASIL DAN PEMBAHASAN}

Hasil

Persiapan kegiatan ini salah satunya dengan melakukan kordinasi dengan pihak yang akan terlibat dengan kegiatan PkM ini seperti menentukan tempat makan (restaurant) untuk melakukan edukasi, kemudian meminta ijin, menyiapkan masker, poster, Mengingat kegiatan ini dilakukan dalam keadaan pandemi yang tidak memperbolehkan terjadinya kerumunan maka kami melakukan dengan cara membagi menjadi empat kelompok dan empat tempat sehingga tidak menjadi suatu kerumunan. Kelompok satu berada di tempat makan (warung gacoan), kelompok 2 Mie Kober, Indomaret di daerah Gatsu Timur, dan di Kopi sehati. Kegiatan yang kami lakukan adalah memberikan edukasi kepada pelanggan tersebut untuk ingat mencuci tangan sebelum masuk ke warung makan, menggunakan masker serta menjaga jarak pada saat duduk.

Selain memberikan edukasi pada pelanggan kami juga membagikan masker dan handsanitaiser. Selain memberikan edukasi kami juga melakukan observasi kepada pelanggan yang sudah ada didalam tempat makan untuk tetap menjaga jarak, menggunakan masker setelah makan. Pada kegiatan ini kami juga memberikan poster kepada warung makan yang memberikan kami ijin untuk melakukan edukasi kepada pelanggannya, hal ini 
bertujuan agar para pelanggan dapat menginggat pentingnya $3 \mathrm{M}$ dalam upaya untuk memutuskan rantai penularan COVID-19 seperti yang sudah seringkali diingatkan oleh pemerintah.

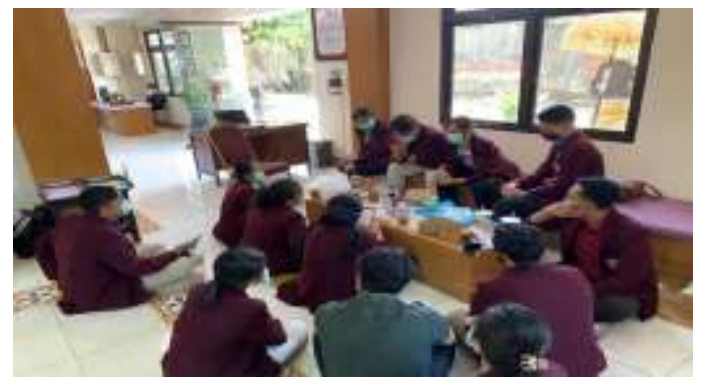

\section{Gambar 1. Persiapan Pelaksanaan PkM Dengan Menentukan Lokasi Kegiatan}

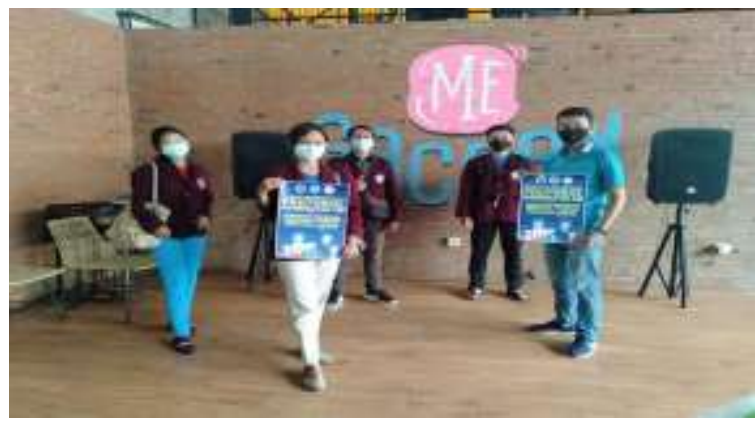

Gambar 2. Penyerahan Poster 3 M

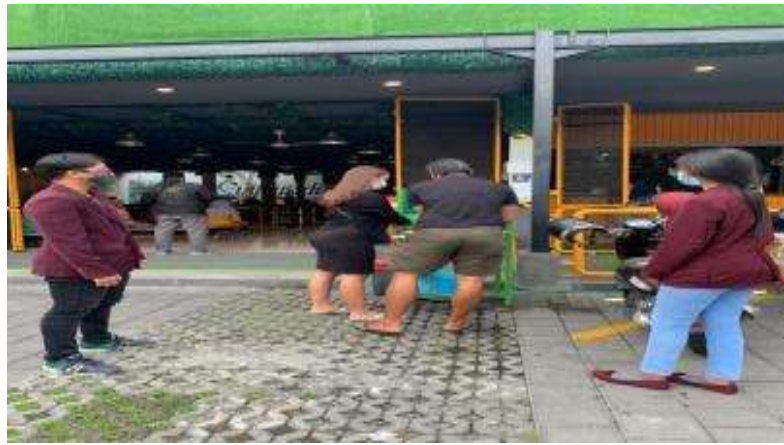

\section{Gambar 3. Melakukan Edukasi Untuk Melaksanakan 3M}

\section{Pembahasan}

Masyarakat Kota Denpasar merespon positif kegiatan PkM ini, terlihat dari antusiasnya masyarakat pada saat mendapatkan edukasi serta mau mengikuti anjuran kami untuk menerapkan 3M. Hal ini sejalan dengan PkM yang dilakukan oleh sulaiman yang mengatakan bahwa masyarakat sangat antusias dalam mengikuti kegiatan penyuluhan tentang COVID-19 dilihat dari banyaknya pertanyaan yang diajukan (Sulaeman \& Supriadi, 2020). Dalam melaksananakan PROKES pemerintah juga sangat mendukung masyarakat untuk menerapkan 3M dalam kehidupan sehari-hari, pernyataan ini diperkuat dengan adanya surat edaran Gubernur Bali salah satunya untuk tidak melakukan kegiatan yang 
menyebabkan kerumunan (Surat-Edaran-Gubernur-Bali-No-71942020-ttg-Panduan-TindakLanjut Pencegahan-Covid-19.pdf, n.d.) terlebih lagi kasus yang meningkat teru sampai dengan saat ini yaitu sebanyak 17.774 kasus (Denpasar Kota, 2021).

Dalam kegiatan PkM ini tentu banyak kekurangannya salah satunya adalah tim kami tidak melakukan evaluasi, sehingga belum mendapatkan hasil yang maksimal dalam hal peningkatan pengetahuan tentang $3 \mathrm{M}$.

\section{KESIMPULAN}

Kesimpulan yang didapatkan dari kegiatan ini adalah masyarakat (pengunjung) mendapatkan pengetahuan dengan adanya edukasi, dan dari poster tentang 3M. Pembagian masker dan hand sanitaizer diharapkan dapat meringankan pemerintah dalam upaya pemutus rantai penularan COVID-19 khususnya di Kota Denpasar.

\section{DAFTAR PUSTAKA}

Badan Pusat Statistik. (2021.). Proyeksi Penduduk Kota Denpasar 2018-2020. Diterima pada 14 January, 2021, Melalui https://denpasarkota.bps.go.id/indicator/12/49/1/proyeksipenduduk-kota-denpasar.html

Denpasar Kota. (2021). Denpasar Save City. Diterima pada 20 Januari 2021, melalui https://safecity.denpasarkota.go.id/index.php

Kementerian Kesehatan Republik Indonesia. (2020). Situasi Terkini Perkembangan Coronavirus Disease (COVID-19). Media Informasi Resmi Terkini Penyakit Infeksi Emerging. http://covid19.kemkes.go.id

P.P Nomor 21 Tentang Pembatasan berskala Besar Dalam Rangka Percepatan Penanganan Corona Virus Disease 2019 (Covid-19), Pub. L. No. 21 Tahun 2020, 2020 (2020). https://jdih.baliprov.go.id/produk-hukum/peraturan/25121

Pemerintah Daerah. (2020). Kawal Covid19. Diterima pada 20 Januari, 2020, melalui https://kawalcovid19.id/pemerintah-daerah

Satuan Tugas Penanganan COVID-19. (2020). Peta Sebaran COVID-19. Diterima melalui https://covid19.go.id/peta-sebaran-covid19

Sulaeman, S., \& Supriadi, S. (2020). Peningkatan Pengetahuan Masyarakat Desa Jelantik Dalam Menghadapi Pandemi Corona Virus Diseases-19 (Covid-19). Jurnal Pengabdian UNDIKMA, 1(1), 12-17. https://doi.org/10.33394/jpu.v1i1.2548

Surat-Edaran-Gubernur-Bali-No-71942020-ttg-Panduan-Tindak-Lanjut-Pencegahan-Covid19.pdf. (n.d.).

World Health Organization. (2020). Coronavirus disease (COVID-2019) situation reports. Diterima melalui https://www.who.int/emergencies/diseases/novel-coronavirus2019/situation-reports 